\title{
EPIZOOTICS AND THE COLONIAL LEGACIES OF THE UNITED STATES IN PHILIPPINE VETERINARY SCIENCE
}

ARLEIGH ROSS D. DELA CRUZ

De La Salle University, Manila, Philippines

\section{Abstract}

The Philippines is an agricultural country highly dependent on water buffalos/carabaos and beef cattle, which are bred and used as work animals and forms of transport. In 1898, American colonial officials, observing the poor health conditions of these animals, noted that many were stricken with infectious contagions. Their death due to communicable animal contagions or epizootics alarmed these officials. Because of this agricultural problem, officials made the control of animal diseases a major focus of colonial policy in the Philippines. Solutions to this problem included the creation of the Bureau of Agriculture and the Bureau of Animal Industry, the establishment of the University of the Philippines College of Veterinary Science, and the implementation of anti-rinderpest serum inoculation, animal quarantine, and anti-rinderpest vaccination. This article analyses the historical development of these government and academic institutions, and examines their important contributions to the development of Philippine environmental and veterinary history. As well, it investigates the significance of other colonial policies implemented by the Americans and how they affected the campaign against animal contagions. Using David Arnold's concept of tropicality, I will also examine how the Americans successfully conquered a particular aspect of the tropical environment-the animal disease problem in the Philippines.

Keywords: epizootics, rinderpest, Bureau of Agriculture, College of Veterinary Science, carabao, tropicality

\section{Introduction}

In 1968, American jurist Charles Burke Elliott wrote in The Philippines to the End of the Commission Government that 'a most serious problem has been the saving of the lives of the draft and other domestic animals from death by diseases'. While in that country, Justice Elliott, Supreme Court Justice in the Philippines from 1909 to 1912, witnessed the death of domestic carabaos, 
beef cattle, and horses due to the spread of infectious animal contagions. ${ }^{1}$ Elliott suggests that it was 'increasingly important to restock the islands with the draft animals with which the Filipinos are accustomed'. ${ }^{2}$

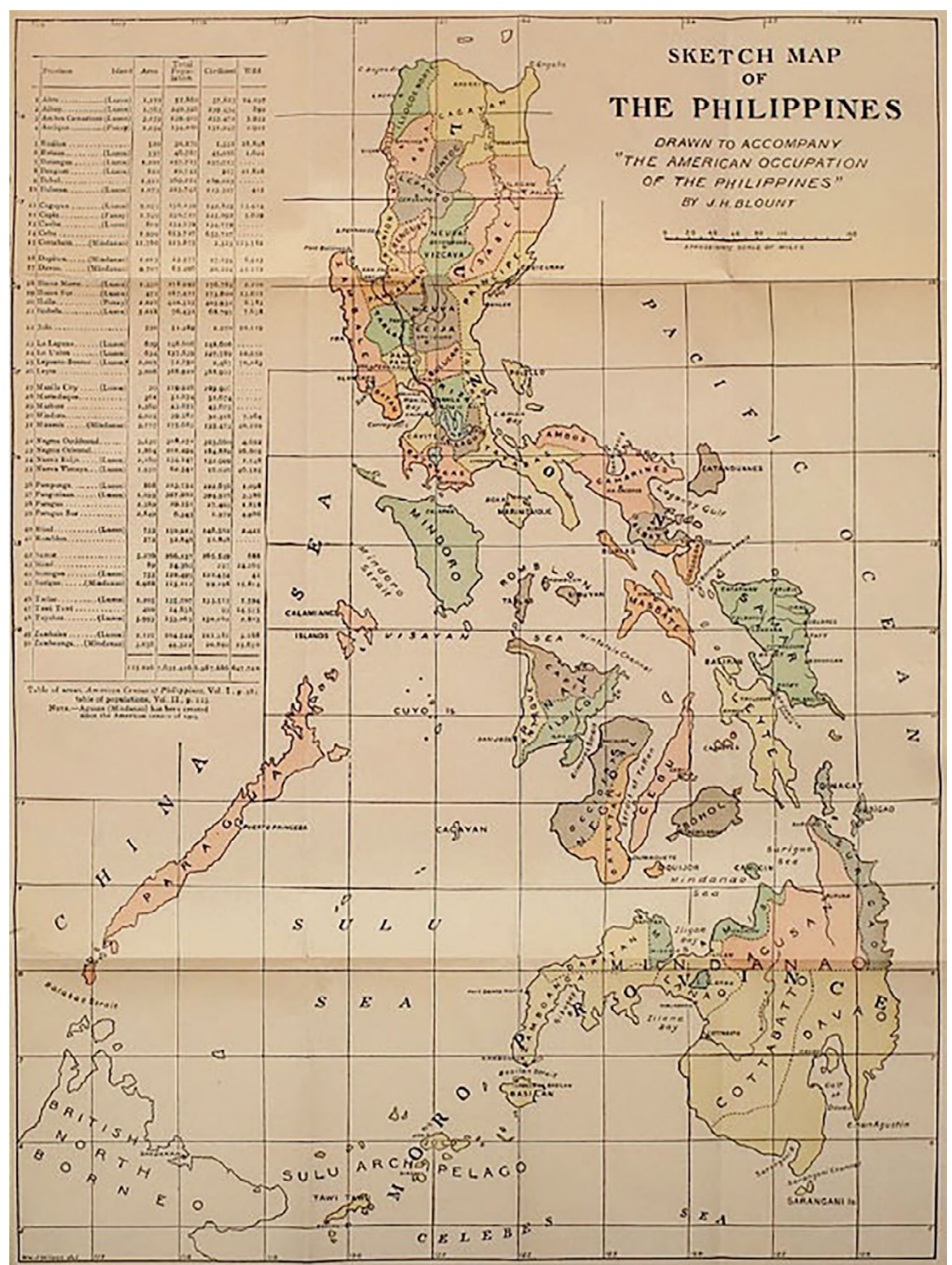

\section{Map 1: Map of the Philippines.}

Source: James H. Blount, The American Occupation of the Philippines, 1898-1912 (New York and London: The Knickerbocker Press, 1912).

1 Charles Burke Elliott, The Philippines to the End of the Commission Government: A Study in Tropical Democracy (New York: Greenwood, 1968), 345-6.

2 Charles Burke Elliott, The Philippines to the End of the Commission Government, 345-6. 
The problem of animal disease haunted the American colonial government following its annexation of the islands in 1898. The agricultural sector of the former Spanish colony was paralysed with the death of thousands of domestic carabaos and cattle throughout the islands due to rinderpest. Considered as an agricultural crisis, the death of domestic animals caused by rinderpest left much farmland and many rice fields untilled.

As the new colonial master of the Philippine archipelago from 1898 to 1946 (Map 1), the United States acted swiftly and urgently to address the crisis in order to save the thousands of domestic animals affected by infectious contagions. Just like their Spanish colonial predecessors, the American colonial government implemented various policies directed towards the protection of carabaos and cattle against epizootics through the application of modern veterinary medical practices. These actions uphold what Greg Bankoff considers to be Western colonisers' 'growing conviction as to the efficacy of their own ability to control the natural world'. ${ }^{3}$ According to David Arnold, Westerners regarded colonies like the Philippines as having 'a hostile and deleterious environment'. ${ }^{4}$ The sense of otherness of the West towards the tropical environment and its 'adverse representations of nature' in the colonies not only included the tropical climate and flora but also encompassed its animal life. ${ }^{5}$

This paper examines how the introduction and development of veterinary science in the Philippines during the American colonial period discloses 'the role of the colonial state as an instigator and active participant in the dissemination and application of scientific knowledge to the imperial venture' ${ }^{6}{ }^{6}$ Colonial belief in the power of 'modern science', particularly the scientific control of animal diseases through modern veterinary practices, offered a way of re-examining the tropical environment during the nineteenth and even in the early twentieth century as both physical and conceptual spaces. ${ }^{7}$ The development of Philippine veterinary science under the Americans proved how the new colonisers, just like their Spanish predecessors, could demonstrate their supremacy over nature and at the same time reduce the country's tropical environment to a new conceptual and physical territory 'over which they could gain mastery and exercise dominion' ${ }^{8}$ The legacy of the changes and scientific developments in veterinary science introduced by the USA into the Philippines remain.

\footnotetext{
3 Greg Bankoff, 'A Question of Breeding: Zootechny and colonial attitudes toward the Tropical Environment in the Late Nineteenth-Century Philippines', Journal of Asian Studies 60, no. 2 (May 2001): 413.

Bankoff, 'A Question of Breeding', 414.

Bankoff, 'A Question of Breeding', 430.

Bankoff, 'A Question of Breeding', 424.

Bankoff, 'A Question of Breeding', 424.

Bankoff, 'A Question of Breeding', 424.
} 


\section{The tropicality discourse and the development of Philippine veterinary science during the American period}

For David Arnold, the tropics are 'a Western way of defining something culturally and politically alien, as well as environmentally distinctive, from Europe and other parts of the temperate zone'. ${ }^{9}$ He argues that Westerners attached a sense of 'otherness' to 'warm countries and tropical places' like the Philippines. These differences were not only evident in colonial descriptions of indigenous societies and cultures, but were also 'reflected in accounts of plants, animals, climate and topography ... particularized through discussion of disease' ${ }^{10}$ In the Philippines, American doctors and veterinary experts viewed the domestic bovine and equine animals, just like their human counterparts, as environmentally alien and so both human and animal contagions were viewed as tropical diseases that were considered distinct compared to those in the 'milder and more temperate lands' ${ }^{11}$

Tropical diseases, whether human or animal, were 'in many respects ... widely different from the diseases of temperate climates' ${ }^{12}$ Arnold notes that because of this condition, 'special knowledge was needed for their diagnosis and successful treatment' ${ }^{13} \mathrm{He}$ believes that tropical diseases led to 'scientific developments, especially the creation of medical specialization in the diseases of "warm climates"'. ${ }^{14}$ In this regard, I seek to explain how the study of animal contagions in the Philippines led to the development of a specialised medical field in the colony-Philippine veterinary science.

In the process of developing scientific solutions to control the spread of animal contagions in the colony, the Philippines was converted into a tropical laboratory intended 'for experiments in disease eradication' ${ }^{15}$ This new trend of disease eradication focused on investigation of the symptoms of a disease and the performance of laboratory experiments in order to control and eventually eradicate the contagion. The Americans converted the Philippines into what might be described as a tropical laboratory to control and eradicate the spread of various infectious animal contagions that struck the country in the nineteenth

9 David Arnold, 'Tropical Medicine before Manson', in Warm Climate and Western Medicine: The Emergence of Tropical Medicine, 1500-1930, ed. David Arnold (Amsterdam: Rodopi, 1996), 6.

10 Arnold, 'Tropical Medicine before Manson', 6.

11 Arnold, 'Tropical Medicine before Manson', 10.

12 Arnold, 'Tropical Medicine before Manson', 3.

13 Arnold, 'Tropical Medicine before Manson', 3.

14 Bankoff, 'A Question of Breeding', 424.

15 David N. Livingstone, 'Tropical Climate and Moral Hygiene: The Anatomy of a Victorian Debate', British Journal for the History of Science 32, no. 1 (March 1999): 107. 
and twentieth centuries. As a tropical laboratory for the control and cure of contagions, the Philippines became an important site for American surgeons, doctors, and veterinary experts to conduct medical research and numerous experiments so that they could determine and understand the etiology of the different animal contagions that infected both the Filipinos and their domestic animals. They also used both the Filipinos and their work animals as laboratory subjects to test various vaccines and sera against the contagions and eventually develop an effective form of cure and treatment against the diseases. ${ }^{16}$

\section{Carabaos and beef cattle in the Philippines}

The Philippine archipelago has fertile lands, rich mineral deposits, and lush vegetation that supports diverse animal life. Part of the diverse animal life in this tropical island country are the domestic carabaos and cattle that serve as draft animals, and which are the backbone of the Philippine agricultural economy because of their important role in rice farming. ${ }^{17}$ In the past and until the present time, Filipino farmers utilised them as beasts of burden in lowland rice-farming provinces, including Pangasinan, Pampanga, Bulacan, Nueva Ecija, Albay, Morong (now Rizal Province), Laguna, Masbate, Mindoro, and Zambales in Luzon; Cebu, Iloilo, and Negros in the Visayas region; and Misamis and Cotabato in Mindanao.

The carabao (Bubalus Bubalis Carabanesis) or water buffalo ('kalabaw' in the Tagalog language) has been described as 'an ungainly quadruped domestic animal, with well-formed, evenly set, and symmetrical spreading horns, black or brown with very scarce body hair ... a large, arched and rough set of horns and a comparatively small head'. ${ }^{18}$ In Hugo Miller's Principle of Economics Applied to the Philippines, he asserts that the carabao is the most important animal for farmers because 'it performs nearly ninety percent of agricultural and transportation work'. Carabaos are utilised 'in preparing the land for planting, in cultivating and in transporting crops to the market' ${ }^{19}$ No wonder the farmer considered them to be so precious that they were housed 'in a comfortable area under his nipa hut and cared for like it was a member of the family'. ${ }^{20}$

16 See Felino S. Garcia Jr, 'The Pathogenic Body in Colonial Science, 1901-1913', Philippine Social Science Review 65, no. 1 (2013): 46-9.

17 Gregorio San Agustin, 'Moral Responsibilities of a Veterinarian', in Philippinensian, by Students of the University of the Philippines (Manila: University of the Philippines, 1916), 179.

18 United States Bureau of Census, Census of the Philippine Islands Taken Under the Direction of the Philippine Commission in the Year 1903 (Washington, DC: Government Printing Office, 1905), 4: 30.

19 Hugo H. Miller, Principles of Economics Applied to the Philippines (Boston, MA: Ginn and Company, 1932), 428.

20 Victor Buencamino, Memoirs of Victor Buencamino (Mandaluyong: Jorge B. Vargas Filipiniana Foundation, 1977), 107. 
Compared with other draft animals, the carabao, notes D. F. Doeppers, is the animal best suited for work in muddy swampy environments and which thrives on poor quality browse'.$^{21}$ The horse, on the other hand, was not utilised as a farm animal in the same way as the carabao because its 'physique and kinetics rendered it unsuitable for employment in the mud of rice paddies' ${ }^{22}$

The importance of the carabao is reflected in its value. According to the 1903 Census, the value of 640,871 head of carabaos in the Philippines was PhP $49,319,755$, or PhP 76.96 per head..$^{23}$ Fifteen years later in 1918 the value of the carabao had increased to PhP 117 per head, an increase of PhP 40.04. ${ }^{24}$ The value of the carabao increased by 52 per cent from 1903 to 1918 because of the epizootics problem that ravaged the domestic supply of carabaos in the Philippines. It was an important problem during the American period because of the carabao's central importance to rice farming.

Just like the value of carabaos, the price of cattle also increased from 1903 to 1918 because of epizootics that killed domestic bovine animals in the Philippines. According to the 1903 census, the total value of 127,559 head of cattle in the Philippines was PhP 6,192,815, with a price per head of PhP 48.55. ${ }^{25}$ This included native cattle (or 'baka' in the Tagalog language), which were utilised mainly as transport animals, and secondarily, for their meat, hide, and horns. This domestic animal thrives in many provinces in the country, namely in Northern Luzon, Mindoro, Masbate, Bataan, Marinduque, Benguet Negros, Leyte, Cebu, Iloilo, Misamis, and Cotabato. ${ }^{26}$ There are also a number of other species of cattle in the Philippines that came from Mexico or China. For example, the red cattle of Mindoro came from China. They are thin but rangy and upright. The Spanish type of cattle that arrived through Mexico has a black or black-and-white coat. This type of cattle thrived in northern Luzon and some parts of the Visayas. ${ }^{27}$

21 D. F. Doeppers, 'Beef consumption and regional cattle husbandry systems in the Philippines, 18501940', in Smallholders and Stockbreeders: History of foodcrop and livestock farming in Southeast Asia, ed. Peter Boomgaard and David Henley (Leiden: KITLV Press, 2004), 314.

22 Bankoff, 'A Question of Breeding', 417.

23 Census of the Philippine Islands Taken Under the Direction of the Philippine Commission in the Year 1903, 4: 225.

24 Government of the Philippine Islands, Department of Commerce and Communications, Bureau of Commerce and Industry, Statistical Bulletin of the Philippine Islands, 1928 (Manila: Bureau of Printing, 1929), 51.

25 Census of the Philippine Islands Taken Under the Direction of the Philippine Commission in the Year 1903, 4: 225.

26 United States Bureau of Insular Affairs, War Department, Report of the Philippine Commission to the President (Washington, DC: Government Printing Office, 1901), 4: 14.

27 Dean C. Worcester, The Philippine Islands and Their People (New York and London: Macmillan, 1899), 512; United States Bureau of Insular Affairs, War Department, Report of the Philippine Commission to the President, 4: 14. 


\section{Epizootics in the colonial Philippines}

The spread of infectious animal contagions or epizootics was a problem that had been noted by colonial officials in Southeast and South Asia since at least the 1600s, and which later affected other colonies in Africa and India. ${ }^{28}$ The Dutch East India Company (VOC) reported cases of epizootic attack among the buffaloes in Sri Lanka as far back as 1647, 1661, 1665, and 1669. In Thailand, VOC writers also mentioned in their reports the decimation of cattle and horses due to epizootics in 1729 and 1732 respectively. Peter Boomgaard concludes that 'throughout the period 1600-1850 epizootics among buffalo were more frequent than cattle epidemics' in Indonesia. ${ }^{29}$ In Java, for example, Thomas Stamford Raffles witnessed how 'Buffaloes ... are subject to an epidemic disease' that 'prevails throughout the whole Island, and generally re-appears after an interval of three, four, or five years: it makes great ravages in the stock of the peasantry'.$^{30}$ Raffles was referring to the devastating attacks of cattle plague or rinderpest that were also later recorded in the island of Java from 1878 to 1881 .

The animal disease problem experienced by the indigenous population in Indonesia, Thailand, Sri Lanka, and South Africa was also present in the Philippines. The attack of infectious animal contagions, or epizootics, among livestock was a problem for the American colonial government because the Philippines was an agricultural country that was highly dependent on the use of carabaos and cattle as draft animals and food. Colonial reports recorded how the contagions killed thousands of domestic carabaos and beef cattle throughout the country. Primary sources and records from the Bureau of Agriculture mention the prevalence of bovine anthrax, foot-and-mouth disease, and even haemorrhagic septicaemia as examples of the epizootics that attacked domestic bovine livestock in the country. ${ }^{31}$ But it must be noted that special attention was given by both the Spanish and the American colonial governments to

\footnotetext{
28 See, for example, Karen Brown, 'Tropical Medicine and Animal Diseases: Onderstepoort and the Development of Veterinary Science in South Africa 1908-1950', Journal of Southern African Studies 31, no. 3 (September 2005): 513-29; 'From Ubombo to Mkhuzi: Disease, Colonial Science, and the Control of Nagana (livestock trypanosomosis) in Zululand, South Africa, c.1894-1953', Journal of the History of Medicine and Allied Sciences 63, no. 3 (July 2008): 285-322.

29 Peter Boomgaard, 'The Age of the Buffalo and the Dawn of the Cattle Era in Indonesia, 1500-1850', in Smallholders and Stockbreeders, ed. Boomgaard and Henley, 262-3.

30 Boomgaard, 'The Age of the Buffalo', 262.

31 See Katherine Mayo, The Isles of Fear: The Truth about the Philippines (New York: Harcourt, Brace and Company, 1925); Bureau of Agriculture, An Order Regulating the Handling of Dangerous and Communicable Animal Diseases', Philippine Agricultural Review 19 (1926): 377-86.
} 
rinderpest, a highly communicable and fatal animal contagion, because of its degree of infectiousness and impact on the country's carabao and beef cattle population. ${ }^{32}$

Rinderpest infects both carabaos and beef cattle and is caused by the rinderpest virus (Paramyxoviridae, genus Morbillivirus), which is found in the blood, faeces, urine, saliva, tears, milk, and various organs of an animal suffering from the disease..$^{33}$ Rinderpest can be transmitted directly from an infected animal to healthy stock through close contact. It can also be transmitted to a healthy animal through direct contact with an infected animal's urine, faeces, saliva, blood, tears, and mucus. An animal that suffers from the contagion initially shows dejection, loss of appetite, and signs of fatigue. After these symptoms, its belly swells and the animal develops a cough, dry muzzle, diarrhoea, and agitated respiration. In the disease's final stages, 'the animal [becomes] emaciated, walks with difficulty and constantly [lies] down'. Those that die of rinderpest have 'truly black blood, sticky, [which] refus[es] to coagulate ... and the intestines are dark reddish-black color and marked with lacerations' ${ }^{34}$

The contagion was introduced into the Philippines in the 1880s when the Spanish Government imported carabaos and cattle from Indo-China, intended for breeding purposes. ${ }^{35}$ When rinderpest was introduced into the country, the Spanish Government was unaware of the pathology of the disease. As a result, isolation measures on imported cattle and carabaos infected with rinderpest from Hong Kong, Hoihau (China), and Indo-China were never implemented. It is estimated that thousands of imported cattle and carabaos infected with the disease were sold and shipped monthly to different provinces in the country. As a consequence, the disease spread rapidly and infected the native stock of bovine animals. ${ }^{36}$

In 1888, rinderpest killed thousands of bovine animals in Bulacan. Carcasses of dead carabaos and cattle were left abandoned in fields and rivers. The vast number of dead animals floating in the water impeded the course of steamships passing by Manila and Bulacan. Even small boats in Bulacan found it difficult

32 Dean C. Worcester, The Philippines: Past and Present (New York: Macmillan, 1930), 413; Greg Bankoff, 'Horsing around: The life and times of the horse in the Philippines at the turn of the twentieth century', in Smallholders and Stockbreeders, ed. Boomgaard and Henley, 249.

33 In the Philippines and other Spanish colonies, the disease is called epizootia; in England and other English colonies it is known as cattle plague; while in Continental Europe and other European countries, the disease is called rinderpest.

34 Greg Bankoff, 'Bestia Incognita: The horse and its history in the Philippines 1880-1930', Anthrozoos 17, no. 1 (2004): 5 .

35 Angel K. Gomez, 'Intensity and Distribution of Infectious Diseases of Animals in the Philippines', Philippine Agriculturist 14, no. 9 (1926): 523.

36 David G. Moberly, 'Common Dangerous Communicable Diseases of Domestic Animals in the Philippine Islands', Philippine Agricultural Review 1 (February 1908): 110. 
to navigate the province's rivers. ${ }^{37}$ Experts estimate that the mortality rate was as high as 90 per cent of the total number of bovine animals in the Philippines. Researcher Ken De Bevoise explains that the impact of rinderpest in the Philippines was great because the native carabao had a very weak resistance to the disease. Since the native stock was never infected by the disease prior to the 1880s, the first rinderpest attack had a high mortality rate. ${ }^{38}$

During the early 1900s, rinderpest continued to spread and create fear among Filipino farmers and American colonial officials alike. In 1900-01, American military authorities estimated that many provinces lost between 50 and 60 per cent of their carabaos and cattle due to this highly infectious animal contagion. ${ }^{39}$ For example, the 1903 census shows that 629,176 carabaos and cattle succumbed to rinderpest. Most deaths were recorded in the Visayas and Mindanao provinces because the plague had already killed thousands of draft animals in Luzon during a previous outbreak of the contagion. ${ }^{40}$

Spanish and then American colonial officials established government agencies to lead the campaign against animal contagions. The Spanish Government tried to control the contagion by professionalising veterinary practice in the Philippines during the latter part of the nineteenth century. The American colonial government created a government agency, namely, the Bureau of Agriculture (later, the Bureau of Animal Industry), to lead and supervise the campaign against epizootics. The Americans also opened an academic institution that became the first veterinary college in Southeast Asia, and implemented a number of policies to control and eradicate the contagions.

\section{Colonial imperatives for the introduction of veterinary science in the Philippines}

The desire to improve the health of domestic animals in the Philippines during the nineteenth century led to the application of the Lamarckian principle of acclimatisation that colonial administrators used as a means to establish 'human mastery not only over inanimate but also over animate nature'.$^{41}$ Bankoff writes that 'animals, especially domesticated animals, were represented as locomotoras

37 Ken De Bevoise, Agents of Apocalypse: Epidemic Disease in the Colonial Philippines (Quezon City: New Day Publisher, 2002), 19.

38 De Bevoise, Agents of Apocalypse, 158.

39 Stanton Youngberg, 'A Brief History of Rinderpest in the Philippine Islands', Philippine Agricultural Review 15 (1922): 205.

40 Census of the Philippine Islands Taken Under the Direction of the Philippine Commission in the Year 1903, 4: 225.

41 Bankoff, 'A Question of Breeding', 424. 
vivientes - living machines or engines susceptible to improvement through breeding' ${ }^{42}$ Aside from animal breeding, improving these 'living machines' was also achieved through the application of modern veterinary science. Later American colonial officials, particularly colonial scientists, believed that through the proper application of colonial science and scientific knowledge, 'humanity could manipulate nature to compensate for any defect of function or pernicious effect of environment'. The pernicious effects of the hot and humid tropical environment of the Philippines on domestic animals became apparent when carabaos and beef cattle became susceptible to bacterial or viral contagions brought about by conditions in the tropics. ${ }^{43}$

The Spanish coloniser's scientific endeavours and achievements have been criticised as 'backward, irrational, and decadent, akin to the Medieval'. ${ }^{44}$ As Bankoff argues, this 'black myth' or leyenda negra was propagated by American colonial officials to differentiate their scientific advances from those of their Spanish predecessors. However, records reveal, according to Bankoff, that the 'Spanish colonial official, foreign naturalist, and the missionary father were as well versed in the science of their day as geographical location and international communications permitted' ${ }^{45}$ But despite their significant scientific contributions to the domains of meteorology, forestry, and botany, not much had been done by the Spaniards to significantly address the animal disease problem in the Philippines.

Veterinary work in the Spanish colonial Philippines started only in the latter part of the nineteenth century. In 1828, a royal decree ordered the appointment of a veterinarian for the Philippines. ${ }^{46}$ This position was created in response to the raising of a regiment of the Spanish cavalry, called the 'dragoons of Luzon'. Initially, the decree called for the appointment of only one veterinarian. However, in 1843 another veterinary position was opened, also through a royal decree. The position of mariscales or government veterinarian, though, was not taken by a graduate of a veterinary course. Any Spaniard who passed the regular veterinary examination board was eligible to be appointed as mariscales. The rules of appointment became stricter after the Royal Decree of 19 August 1847 revised the veterinary course in Spain. Henceforth, only graduates in veterinary medicine were eligible for appointment as veterinarians. Those who already practised the profession prior to 1847 were given three years to finish

\footnotetext{
42 Bankoff, 'A Question of Breeding', 424.

43 Bankoff, 'A Question of Breeding', 424.

44 Garcia, 'The Pathogenic Body', 36.

45 See Greg Bankoff, 'The Science of Nature and the Nature of Science in the Spanish and American Philippines', in Cultivating the Colonies: Colonial States and their Environmental Legacies, ed. Christina Folke Ax et al. (Athens, OH: Ohio University Press, 2011), 78-108.

46 Gregorio San Agustin, 'Meat Inspection in the Philippines', Philippine Journal of Animal Industry 3, no. 6 (November-December 1936): 519.
} 
their veterinary medicine degrees. Because of the new rules, veterinarians in the Spanish army were from 1855 called profesores de veterenaria or veterenarios. Veterinarians in the Spanish army were given military ranks. They also became part of the Spanish Veterinary Corps. The employment of veterenarios in the Spanish Army continued until the end of the Spanish regime in $1898 .{ }^{47}$

The Spanish Veterinary Corps was the principal agency tasked with controlling animal diseases in the Philippines. It was mandated to preserve the health of animals in the Spanish army. It was also duty-bound to treat animal contagions, conduct meat inspection in the matadero or slaughterhouse of Manila, and serve as sanitary police. In addition, it was tasked with training cavalry animals. ${ }^{48}$ The army veterinarians' knowledge of animal science was put to the test when the great rinderpest epidemic killed 90 per cent of the carabao and cattle population in the Philippines during the late $1880 \mathrm{~s} .{ }^{49}$ The high mortality of bovine animals due to the plague alarmed the Spanish Government. As a response to the problem, Spanish veterinary officials informed people about the necessary treatment against the disease. Announcements made by the government recommended the use of purgatives as a cure and the cleaning of premises where an animal died as a preventive measure. ${ }^{50}$

Bankoff argues that even though the Spaniards professionalised scientific knowledge and elevated veterinary science to a specialised discipline in the Philippines during the nineteenth century, veterinary medicine and care of domestic animals 'came a poor second to questions of interhuman competition despite the establishment of a policia sanitaria', which was responsible for the maintenance of animal health conditions. ${ }^{51}$ Bankoff concludes that the decline of Spanish scientific knowledge and expertise, including veterinary science, can be attributed to the Spanish Government's failure 'to survive the transition to modernity as well, neither as a model nor in knowledge production'.$^{52}$ 'As Spanish power waned', Bankoff writes, 'it fell increasingly under foreign influence and failed to develop a firm scientific, technological, or industrial base of its own. ${ }^{53}$

\footnotetext{
47 Vicente Ferriols, 'Early History of Veterinary Science in the Philippine Islands', in Encyclopedia of the Philippines, ed. Zoilo Galang (Manila: Exequiel Floro, 1957), 332-4, 338.

48 Ferriols, 'Early History of Veterinary Science', 333-4.

49 Bankoff, 'Bestia Incognita', 5.

50 Philippines Bureau of Agriculture, 'Rinderpest under the Spanish Regime', Philippine Agricultural Review 3 (1910): 368; United States Bureau of Insular Affairs, War Department, Report of the Philippine Commission to the President (Washington, DC: Government Printing Office, 1903), 365.

51 Bankoff, 'Horsing around', 248-9.

52 See Bankoff, 'The Science of Nature', 89.

53 Bankoff, 'The Science of Nature', 89.
} 
A new and different story unfolds with the occupation of the Philippines by the United States in 1898. In a 1911 Manila Times article, W. E. Musgrave, an American doctor and former dean of the Philippine General Hospital, proudly announced to the world that 'the history of scientific progress in the Philippines begins with our occupation of the islands'. ${ }^{54}$ Musgrave's announcement summarises the boastful scientific achievements of the Americans in their newly acquired colony, a tradition of scientific advancement that followed British scientific traditions. ${ }^{55}$

Dean Worcester, the first American Secretary of the Interior of the American civil government in the Philippines (1901-13), was one of the first American colonial officials in the islands to witness the poor health conditions of domestic animals there. In his book, The Philippines: Past and Present, Worcester writes:

Rinderpest, a highly contagious and very destructive disease of horned cattle, was introduced in 1888 and spread like fire in prairie grass. No real effort was made to check it prior to the American occupation, and it caused enormous losses, both directly by killing large numbers of beef cattle and indirectly by depriving farmers of draft animals. ${ }^{56}$

Worcester's observations of the epidemic diseases that struck domestic animals in the Philippines crystalised America's responsibility to control the tropical environment of the Philippines, through the control and eradication of the animal contagions that were killing off carabaos and cattle.

\section{The development of Philippine veterinary science under the star-spangled banner}

As the United States started its campaign against animal contagions, its primary concern was to establish 'a more comprehensive institutional and legal structure with which to tackle animal diseases' ${ }^{57}$ To make this goal concrete, American military, health, and veterinary officials established government institutions to implement programmes to control epizootics.

At the start of American rule in the Philippines in 1898, there was no single government agency tasked with supervising the campaign against animal diseases. Because of this, the American military government (1898-1901), through the Office of the Provost-Marshal-General, implemented a number of ordinances to ensure the safety and protection of domestic animals from

54 Garcia, 'The Pathogenic Body', 36.

55 See Bankoff, 'The Science of Nature', 89-90.

56 Worcester, The Philippines, 413.

57 Bankoff, 'Horsing around', 249. 
epizootics. For example, the Provost-Marshal-General was authorised to craft policies and health regulations in the form of municipal ordinances for the city of Manila. ${ }^{58} \mathrm{He}$ also established a veterinary department under the supervision of the Board of Health tasked with ensuring that diseases among domestic animals were properly checked and monitored. In practical terms, the veterinary department inspected all cattle entering Manila and all animals butchered in the slaughterhouse; took care of domestic animals; and checked the sanitary conditions of public and private stables. The veterinary department comprised one veterinarian and three Filipino animal inspectors. ${ }^{59}$

This structure changed when the civil government in the Philippines was established on 4 July 1901. As far as animal disease control was concerned, this function was placed under the Insular Board of Health, the Serum Laboratory, and the Bureau of Agriculture. The Insular Board of Health was established to supervise public health and the health of domestic animals in the Philippines, ${ }^{60}$ and comprised a Commissioner of Public Health, a Sanitary Engineer, a Chief Health Inspector, a Superintendent of Government Laboratories, and a Secretary. ${ }^{61}$ The Americans also recognised laboratory science as being key to the control and eradication of animal diseases. Accordingly, in July 1901 they set up the Serum Laboratory, ${ }^{62}$ which was later incorporated into the Vaccine Institute to improve the production of vaccines. ${ }^{63}$

The civil government also created a Veterinary Corps in 1901 under the direct supervision of the Director of the Serum Laboratory. Its task was to inoculate all animals infected with dangerous and communicable diseases. In 1904, the Veterinary Corps became a Veterinary Division under the Board of Health. ${ }^{64}$ It consisted of 'nine veterinarians and 20 inoculators charged among other duties with inspecting animals entering the country'.$^{65}$

58 United States Bureau of Insular Affairs, War Department, Report of the Philippine Commission to the President, 1901 (Washington, DC: Government Printing Office, 1902), 2: 1162.

59 Philippines Bureau of Agriculture, 'The Animal-Disease Control Problem', Philippine Agricultural Review 1, no. 5 (1908): 186-93; United States Bureau of Insular Affairs, Report of the Philippine Commission, 1904 (Washington, DC: Government Printing Office, 1905), 2: 204-5.

60 George R. Harvey, 'Certain Legal Phases of the Work of the Government Veterinary Surgeons', Philippine Agricultural Review 1 (1908): 416.

61 United States Bureau of Insular Affairs, Report of the Philippine Commission, 1902 (Washington, DC: Government Printing Office, 1903), 1: 381.

62 United States, Philippine Commission, Public Laws passed by the Philippine Commission during the Period from September 1, 1902 to August 31, 1903 (Manila: Bureau of Public Printing, 1904), 263-4; United States Bureau of Insular Affairs, Report of the Philippine Commission, 1902 (Washington, DC: Government Printing Office, 1903), 1: 549.

63 United States, Philippine Commission, Public Laws passed by the Philippine Commission during the Period from September 1, 1902 to August 31, 1903, 263-4; United States Bureau of Insular Affairs, Report of the Philippine Commission, 1902 (Washington, DC: Government Printing Office, 1903), 1: 549.

64 United States Bureau of Insular Affairs, Report of the Philippine Commission, 1904 (Washington, DC: Government Printing Office, 1905), 2: 48, 416, 449.

65 Bankoff, 'Horsing around', 249. 
An additional agency involved in disease control was the Insular Bureau of Agriculture (established in October 1901). This comprised a bureau chief, an expert in animal industry, a botanist, an assistant agrostologist, a soil expert, a tropical agriculturist, an expert in plant culture and breeding, and an expert in farm machinery and farm management. ${ }^{66}$ It was tasked with investigating and disseminating important information about livestock, dairy, and other animal industries. The introduction of new, and the improvement of existing, breeds of domestic animals formed another function of the Bureau. A third was ensuring the safety of imported animals used for serum production, breeding, and food consumption. ${ }^{67}$

Further restructuring occurred. In 1905, the Philippine Commission, in accordance with the Reorganization Act (No. 1407), integrated the animal disease control functions of the Board of Health and Bureau of Agriculture into a single agency. ${ }^{68}$ Section $5(\mathrm{~d})$ of this Act transferred the supervision of the Veterinary Division, which was previously under the Board of Health, to the Animal Industry Division of the Bureau of Agriculture. ${ }^{69}$ In 1919, the Bureau of Agriculture underwent further reorganisation when the Animal Industry Division was abolished and its functions were delegated to the Veterinary Division of the Bureau of Agriculture. During this period, the Veterinary Division directly supervised government veterinary research, animal disease control and quarantine, and meat inspection. ${ }^{70}$

The Veterinary Research Laboratory was a facility established to study the pathology and causes of animal diseases, together with their prevention and possible cure. It also manufactured vaccines, sera, and other biological products not produced by private companies. ${ }^{71}$ The Animal Disease Control Division was responsible for the control and eradication of infectious animal diseases, including preventing their entry into the country. It was also in charge of the

66 United States Bureau of Insular Affairs, Report of the Philippine Commission, 1902 (Washington, DC: Government Printing Office, 1903), 1: 298-9, 587.

67 United States Bureau of Insular Affairs, Report of the Philippine Commission, 1902 (Washington, DC: Government Printing Office, 1903), 1: 588; Commonwealth of the Philippines Department of Agriculture and Commerce, The Livestock Industry in the Philippines (Manila: Bureau of Printing, 1939), 7.

68 United States, Philippine Commission, Public Laws Passed by the Philippine Commission during the Period from September 1, 1905 to August 31, 1906 (Manila: Bureau of Public Printing, 1907), 79-83.

69 United States House of Representatives, Annual Report of the War Department for the Fiscal Year Ended June 30, 1905: Acts of the Philippine Commission and Public Resolutions from September 1, 1904 to October 31, 1905 (Washington, DC: Government Printing Office, 1905), 242-4.

70 United States Congress, Senate, Report of the Governor General of the Philippine Islands to the Secretary of War, 1921 (Washington, DC: Government Printing Office, 1921), 180.

71 Philippines Department of Agriculture and Commerce, Bureau of Animal Industry, Animal Industry Administrative Order No. 1 (15 August 1933), 79-80. 
operation of 'a system of inspection of meat, dairy farms, ports, railway stations and shipping centers' and the control and regulation of animal movements within towns, provinces, and islands throughout the country. ${ }^{72}$

The Animal Quarantine Division controlled the strict enforcement of quarantine rules, animal movement regulations, and vaccination policies. The Meat Inspection Section was responsible for the maintenance and establishment of municipal slaughterhouses and the inspection of dairy farms. It was tasked with ensuring that all animals sold and slaughtered were safe to be eaten, and enforced rules for the regulation and maintenance of dairy farms. ${ }^{73}$

In the 1930s, the government bureaucracy was further reorganised to maximise the greatest efficiency pursuant to the needs of the time. In 1929, the functions of the Bureau of Agriculture were transferred to the Bureau of Animal Industry and the Bureau of Plant Industry. This completely stripped the Bureau of Agriculture of all duties and functions involving animal disease control. Henceforth, the Bureau of Animal Industry became the sole agency tasked with all matters pertaining to animal disease control. In 1930, the Bureau of Animal Industry was established to investigate, study, and report on the conditions of domestic animals in the Philippines. The practical functions of the Bureau included finding ways to improve methods of animal reproduction, inquiring and reporting on the causes of dangerous communicable animal diseases in the Philippines, and lastly, controlling and eradicating the spread of infectious animal diseases in the country. ${ }^{74}$

The Bureau of Animal Industry had four divisions: the Administrative Division, the Animal Disease Control Division, the Veterinary Research Division, and the Animal Husbandry Division. ${ }^{75}$ The Veterinary Research Division had four sections: Immunology, Bacterial Diseases, Biochemical Diseases, and Parasitic Diseases. ${ }^{76}$ The Bacterial Diseases Section studied the epizoology, diagnosis, prevention, and treatment of various bacterial diseases of animals. The Parasitic Diseases Section examined the nature of various parasitic diseases of animals in the Philippines and researched the treatment of different unknown parasites. ${ }^{77}$

\footnotetext{
72 Sergio Osmeña, 'Address by the Guest of Honor', Philippine Journal of Animal Industry 3, no. 2 (1936): 80. 73 Osmeña, 'Address by the Guest of Honor', 80. See also Commonwealth of the Philippines Department of Agriculture and Commerce, Bureau of Animal Industry, Annual Report of the Bureau of Animal Industry for the Fiscal Year Ending December 31, 1938 (Manila: Bureau of Printing, 1939).

74 Philippine Legislature, Public Laws Enacted by the Philippine Legislature during the Period August 9, 1929 to February 7, 1930 (Manila: Bureau of Printing, 1930), 352-5.

75 Commonwealth of the Philippines Department of Agriculture and Commerce, The Livestock Industry in the Philippines (Manila: Bureau of Printing, 1939), 10-11.

76 Commonwealth of the Philippines Department of Agriculture and Commerce, Administrative Order No. 1 (15 August 1933), 79-80.

77 Commonwealth of the Philippines Department of Agriculture and Commerce, Administrative Order No. 1, 79-80; Commonwealth of the Philippines, Annual Report of the Bureau of Animal Industry for the Fiscal Year Ending December 31, 1938.
} 
While these institutions and legislation were impressive on paper, their ability to successfully carry out these tasks was another matter. As the following paragraphs show, quarantine faced resistance from local people, while personnel shortages dogged the veterinary service, which was unable to successfully develop a serum against rinderpest until the 1930s.

\section{Serum inoculation}

The Bureau of Agriculture introduced in the latter part of 1902 the immediate inoculation of susceptible animals with the anti-rinderpest serum. The serum was extracted from the blood of an animal that had been infected with the rinderpest virus but had fully recovered. Experiments showed that the serum of an animal that recovered from rinderpest was able to provide immunity to susceptible animals. The potency of the serum depended on the animal's reaction when it was still suffering from the disease. For example, animals that suffered a mild form and suffered only low fever produced a less potent serum. Injection of a highly potent serum in healthy animals gave temporary immunity from rinderpest for one to two months. In some cases, it was an effective curative agent against rinderpest, especially if it was given early. ${ }^{78}$

Veterinary surgeons and inoculators used two methods of inoculation. These were the simultaneous inoculation and the serum-alone methods. The simultaneous or mixed method was conducted by injecting under the skin of a healthy animal $30 \mathrm{ml}$ of anti-rinderpest serum and $1 \mathrm{ml}$ of virulent blood or blood from a sick animal. This method gave healthy animals the disease and the remedy at the same time. Experiments showed this method gave a longer period of immunity, resulting in only a very slight attack of the disease. ${ }^{79}$ On the other hand, the serum-alone method was conducted by injecting only the anti-rinderpest serum under the skin of a healthy animal. This method was adopted in the country because British veterinarians had used it effectively for several years in India. ${ }^{80}$

In 1903, veterinary surgeons and inoculators used both inoculation methods in different provinces in the country. It was during these trials that the Bureau of Agriculture observed the weakness of both inoculation methods. After four years of use, the simultaneous method produced heavy losses. Its failure

78 H. F. Kern, 'The Use of Anti-Rinderpest Serum in the Field', Philippine Agricultural Review 15 (1922): 241; Teodulo Topacio, 'The Manufacture of Anti-Rinderpest Serum in the Philippine Islands', Philippine Agricultural Review 15 (1922): 230-1.

79 United States Bureau of Insular Affairs, Report of the Philippine Commission, 1903 (Washington, DC: Government Printing Office, 1904), 2: 378; United States Bureau of Insular Affairs, Report of the Philippine Commission, 1905 (Washington, DC: Government Printing Office, 1906), 2: 47 and 117; Manuel M. Robles, 'Experiments on the Virulence of Rinderpest Blood', Philippine Journal of Animal Industry 2, no. 4 (1931): 307. 80 United States Bureau of Insular Affairs, Report of the Philippine Commission, 1903 (Washington, DC: Government Printing Office, 1904), 2: 378. 
was undoubtedly due to the lack of adequate field trials. ${ }^{81}$ For one thing, the Bureau did not conduct experiments to test the effectiveness of the method. They did find out that virulent blood obtained in a haphazard manner did not ensure uniformity of virulence. Moreover, many bovine animals died because veterinarians and inoculators did not consider the condition of the animals when they were being inoculated. Because of the ineffectiveness of the simultaneous method, veterinary officials stopped its field application in $1907 .{ }^{82}$

The failure of the simultaneous method led the Bureau of Agriculture to shift to the serum-alone method. Colonial officials thought that its application was effective. Unfortunately, just like the simultaneous method, the serum-alone method was also a failure. It provided only temporary immunity that lasted from seven to 14 days. The immunity that it provided lasted only so long as it was still circulating in the animal's system. After it had been eliminated from the body, the animal was again susceptible to the disease. So when this method was employed in the field, many native cattle and carabaos died because they again became highly susceptible to the disease. The method was also discontinued because it was very expensive. Results of field trials showed that an animal needed to be injected with 20 to $30 \mathrm{ml}$ of serum for 10 to 15 times but despite this it acquired only temporary immunity. For these reasons, the use of the serum-alone method was discontinued in $1911 .^{83}$

Aside from the ineffectiveness of treatment, many Filipino farmers did not cooperate with inoculation. They expected the American veterinarians and inoculators to give medicine to their sick carabaos or cattle, but they were astounded when they saw veterinarians injecting into their beloved carabao blood from a sick animal. Many Filipino farmers became angry with American veterinarians because they thought that the injection of virulent blood did not cure but only aggravated the condition of their animals. Moreover, the inoculation method became very unpopular among farmers because of the high mortality rate. In the official reports of the inoculators, the death rate incurred following the inoculation of bovine animals in some areas was as high as 50 per cent. ${ }^{84}$ This high level of mortality made many farmers resent the programme and act violently whenever American inoculators came to vaccinate their work animals. In the memoirs of Dr Victor Buencamino, the first

81 Rodney Sullivan, Exemplar of Americanism: The Philippine Career of Dean C. Worcester (Quezon City: New Day Publishers, 1992), 102-3.

82 Angel Gomez, 'Eradication and Control of Rinderpest in the Philippine Islands,' Journal of the American Veterinary Medical Association 113, no. 857 (August 1948): 112; Moberly, 'Common Dangerous Communicable Diseases', 117-18.

83 Kern, 'The Use of Anti-Rinderpest Serum in the Field', 243; Youngberg, 'A Brief History of Rinderpest in the Philippine Islands', 207-9, 215.

84 United States Bureau of Insular Affairs, Report of the Philippine Commission, 1904 (Washington, DC: Government Printing Office, 1905), 2: 21; and Sullivan, Exemplar of Americanism, 102-3. 
Filipino veterinarian, he mentions 'many cases of violence, of farmers chasing government veterinarians away with bolos' to prevent their animals from being inoculated. Because of the antagonistic response of Filipinos to the inoculation policy of the colonial government, his 'team had to be accompanied by platoons of Philippine Scouts' ${ }^{85}$ Proof of the intense opposition of many Filipino farmers to the veterinary forces of the colonial government was the term 'precursors of evil', which they gave to the American veterinarians. The term was coined because everywhere the American veterinarians went to conduct inoculations, many of the animals died. In some areas, farmers even hid their animals in the mountains to escape the inoculators. ${ }^{86}$

\section{Quarantine programme}

American policies to control animal contagions were patterned after British veterinary practices. American veterinary officials subscribed to the contagionist perspective in veterinary science and the importation theory of animal diseases theorised by British scientists. John Gamgee, the English principal of the New Veterinary College in Edinburgh in the late 1850s, developed this perspective on veterinary science. Its proposition was that infectious animal contagions 'could be passed on via an intermediate agency or host as well as by direct contact' ${ }^{87}$ Contagionists believed that animal diseases were caused by 'foreign or external agents that invaded an otherwise healthy system, eventually disrupting or destroying its normal functioning ${ }^{\prime}{ }^{88}$ This theory was postulated in the nineteenth century when the British Government faced threats of animal contagions. Under this theory, the infective agents of animal disease were diseased cattle; the system infected was the livestock economy; and the infection was introduced through importation. As a result of this theory, the British Government implemented administrative control measures that 'sought to keep out and stamp out any and every animal contagion that threatened the livestock industry' ${ }^{89}$ These policies were implemented through the passage of legislative orders that allowed the exclusion of affected beasts through quarantines and port inspections.

In the Philippines, the Bureau of Agriculture adopted the strict implementation of the animal quarantine policy because it realised that any method aimed at the eradication of animal diseases was ineffective so long as the movement of infected

85 Buencamino, Memoirs, 107-8.

86 Buencamino, Memoirs, 107-8.

87 Michael Worboys, Spreading Germs: Disease Theories and Medical Practices in Britain, 1865-1900

(Cambridge: Cambridge University Press, 2000), 48, 57.

88 Worboys, Spreading Germs, 71.

89 Worboys, Spreading Germs, 71. 
animals between barrios, towns, and provinces was not controlled. With this in mind, the Bureau implemented a more serious and stricter campaign to control the spread of epizootics in the country.

On 10 October 1907, the Philippine Commission passed Act No. 1760, which prohibited 'any person, firm or corporation from shipping or bringing into the country any domestic animal that was suffering from, infected with or [had] died of dangerous communicable diseases'. The Act also prohibited 'the transfer, shipping or transport from one island, province, municipality, township or settlement to another domestic animals infected with any infectious animal disease or to expose such animal, either dead or alive, on any public road, street or highway where it may come in contact with other domestic animals'. The Act appointed the Director of Agriculture head of the animal disease control campaign, empowering him to provide permits, quarantine, cremate, and dispose of all imported and domestic animals from ports or places infected with contagious diseases. The same Director of Agriculture was also authorised to inspect all domestic animals arriving by boat, rail, or otherwise in cities, ports, or other places to prevent the entry and spread of infectious communicable diseases within the Philippines. ${ }^{90}$ With the enactment of Act No. 2172 in 1912, the Director of Agriculture was given powers to strictly impose the quarantine policy. He was empowered to place under quarantine any province, island, municipality, barrio, township, settlement, parcel of land, or district of whatever size if the area was determined to have been infected by an infectious animal disease. The Act authorised the Director of Agriculture to isolate infected animals and to place them in quarantine stations. The Act also prohibited all persons, railroad company employees, and owners or masters of any steam or sailing vessel or boat in any place declared under quarantine to receive or to deliver for transport or transportation from and to any quarantined province, island, municipality, barrio, parcel of land, or district any domestic animal without the written permission of the Director of Agriculture. ${ }^{91}$ In order to ensure compliance with the quarantine policy, the Bureau of Agriculture established permanent quarantine stations in key areas throughout the country. Quarantine stations were built in Manila, Pandacan, Iloilo, and Cebu to ensure that susceptible imported animals did not spread animal contagions in the country. ${ }^{92}$

90 United States War Department, Annual Report, 1907: Acts of the Philippine Commission and Public Resolutions from September 16, 1906 to October 31, 1907 (Washington, DC: Government Printing Office, 1907), 445-7.

91 United States, Philippine Commission, Public Laws Enacted by the Philippine Legislature during the Period January 1, 1910 to October 15, 1912 (Manila: Bureau of Printing, 1912), 343.

92 Bankoff, 'Horsing around', 249. 
Like inoculation, animal quarantine was severely opposed by many Filipino farmers and its laws usually violated by Filipino animal owners because it went against their regular routine. Farmers pastured their animals during the day and allowed them to move and mingle freely after work in the river or in muddy swamps. Unfortunately, when the quarantine measures were implemented in 1912, sick carabaos and cattle were isolated and placed in roofless corrals constructed by the government. Many Filipino farmers considered the quarantine measures worse than the disease itself because they separated them from their farming partner, the carabao.

Farmers defied quarantine regulations by removing their animals from quarantine corrals and hiding them in the mountains where the government's search teams would be unable to find them. In other districts, farmers submitted their animals for quarantine but asked for work passes during the night in order to pasture their animals. Others did not even apply for passes. They just took their animals out of the isolation corrals and pastured them. ${ }^{93}$ Quarantine detached the farmer from his sick animal and this was seen by farmers as a severe policy that failed to consider the significance of the carabao to the Filipino farmer. ${ }^{94}$ Historian John Larkin cites an instance in Pampanga, a province in Luzon, where Filipino farmers frequently violated the quarantine policy implemented by the government:

By late 1912 and early 1913 the situation became critical. Farmers evaded the quarantine and brought infected animals to clean areas ... Farmers and veterinarians countered each other's move with evasion and strict controls. Tensions sprang up. At one point a farmer from Arayat, Andriano Panlilio, with a group of armed men chased the vets off his property. ${ }^{95}$

The implementation of the quarantine programme did not produce positive results. Data reveal that the number of deaths due to rinderpest increased four years after the policy was implemented. When the programme was implemented in 1912, only 2,847 deaths were recorded. Four years after the policy was implemented, the number of deaths recorded increased to 18,251. In 1917, the number of deaths ballooned to 26,951 . Table 1 shows the number of deaths due to rinderpest in 1912-17.

93 C. H. Decker, 'Rinderpest in the Amburayan River Valley', Philippine Agricultural Review 6 (1913): 392-3; Pablo Ocampo Y Tecson, 'The Relations Existing Between the Bureau of Agriculture and the Provincial and Municipal Governments in the Suppression of Infective Animal Diseases', Philippine Agricultural Review 1, no. 10 (1908): 422; Stanton Youngberg, 'Resume of the Work of the Veterinary Division for the Year 1916', Philippine Agricultural Review 10 (1917): 177.

94 This behaviour was common among Filipino farmers. See John Larkin, The Pampangans: Colonial Society in a Philippine Province (Berkeley, CA: University of California Press, 1972).

95 Larkin, The Pampangans, 259. 
Table 1: Number of deaths due to rinderpest, 1912-17.

\begin{tabular}{|l|l|}
\hline Year & Deaths \\
\hline 1912 & 2,847 \\
\hline 1913 & 2,787 \\
\hline 1914 & 2,715 \\
\hline 1915 & 2,305 \\
\hline 1916 & 18,251 \\
\hline 1917 & 26,951 \\
\hline
\end{tabular}

Source: Commonwealth of the Philippines. Annual Report of the Bureau of Animal Industry for the Fiscal Year Ending December 31, 1938 (Manila: Bureau of Printing, 1939), 72.

Dr Victor Buencamino, the first Filipino veterinarian to serve as an official in the Bureau of Agriculture, sympathised with the Filipino farmer's plight and condition. Buencamino believed that the quarantine policy was contrary to the Filipino's culture. In his memoir, he writes:

government men were taking his carabao away and confining it in a roofless corral with strange animals of other farmers and [giving it] strange medicine that was known to have killed more than cured. And on top of it all, the poor farmer had to lug his carabao feed over his own shoulders all the way to the quarantine site. Naturally the farmer rebelled against this. ${ }^{96}$

Filipino local officials also did not support the colonial government's quarantine policy. They were supposed to help the Bureau of Agriculture implement the quarantine policies in their respective areas but they did not implement the policy because of fears that they would not win the local elections. Instead of strictly implementing the quarantine regulations, many local officials allowed farmers to evade quarantine policies.

The American colonial government attributed the popular prejudice and 'indifference, amounting at times to active opposition of people and officials to the work ${ }^{\prime 97}$ to the 'ignorance or superstition' of the Filipinos. ${ }^{98}$ Filipinos simply did not understand the scientifically tested programmes against infectious animal diseases.

\footnotetext{
96 Buencamino, Memoirs, 107.

97 United States Bureau of Insular Affairs, Report of the Philippine Commission (Washington, DC: Government Printing Office, 1911), 183-4.

98 United States Bureau of Insular Affairs, Report of the Philippine Commission, 1908 (Washington, DC: Government Printing Office, 1909), 2: 53.
} 


\section{The University of the Philippines College of Veterinary Science: America's veterinary college in the tropical island colony}

In addition to the ineffectiveness of both inoculation and quarantine, there was a third problem related to the colonial government's inability to hire a sufficient number of American veterinarians to implement the animal disease control campaign in the provinces. Most of the American veterinary experts who were hired to work in the colony immediately returned home after their contracts expired. ${ }^{99}$ Many American veterinarians could not be enticed to work in the Philippines because the colonial government could not offer high enough salaries. Well-qualified veterinarians commanded high salaries in the United States that the American colonial government found difficult to match. The continuous recruitment and appointment of veterinarians from the United States drained the country's Insular Treasury. ${ }^{100}$

The scarcity of American veterinarians made it extremely difficult to respond immediately to the needs of provinces affected by colonial epizootics. Due to the lack of veterinary personnel, the Bureau of Agriculture had no choice but to respond only to calls where serious outbreaks of animal contagions were prevalent or appeared to be widespread. Officials of the Bureau confessed that their pool of veterinary experts and personnel was much too small to handle the gargantuan task of controlling and later eradicating the widespread incidence of infectious animal diseases in the Philippines. ${ }^{101}$ In 1908, the Bureau admitted this problem in its annual report:

Due to lack of sufficient veterinarians, it is impossible to respond to the calls of provinces affected by epizootics. The Bureau has necessitated [sic] responding to calls only where the outbreaks of disease appeared to be serious and has resulted in some small outbreaks assuming a serious aspect before attention could be given to them. Owing to [the] widespread prevalence of rinderpest, [and] footand-mouth disease ... our veterinary force is still too small to satisfactorily handle the work. ${ }^{102}$

99 Philippine Veterinary Medical Association, 'Opening Address of Dr. Vicente Ferriols, President of the Philippine Veterinary Medical Association, February 20, 1940', Philippine Journal of Animal Industry 8, no. 3 (1941): 196-7; A. K. Gomez, 'Development of Veterinary Medicine in the Philippines', Bulletin of National Research Council of the Philippine Islands (1935): 341.

100 United States Bureau of Insular Affairs, Report of the Philippine Commission to the Secretary of War, 1911 (Washington, DC: Government Printing Office, 1912), 181.

101 Philippine Bureau of Agriculture, 'Report of the Bureau of Agriculture for the Fiscal Year Ending June 30, 1908', Philippine Agricultural Review 2 (1909): 6.

102 Philippine Bureau of Agriculture, 'Report of the Bureau of Agriculture for the Fiscal Year Ending June $30,1908^{\prime}, 6$. 
The scarcity of well-trained veterinarians in the Philippines was a lingering problem for many years. ${ }^{103}$ Aware of the need to address the problem of securing competent American veterinarians, Dean C. Worcester, Secretary of the Interior, made a brilliant suggestion in 1907 . He recommended 'that early consideration should be given [to] the question of the advisability of establishing here [in the Philippines] a veterinary school' ${ }^{104}$ In this regard, Worcester reported that 'the first college of the proposed new University to be established should be a College of Veterinary Medicine and Surgery' ${ }^{105}$ The efforts of Secretary Worcester and Dr Archibald Ward, chief veterinarian of the Bureau of Agriculture, bore fruit with the establishment of the College of Veterinary Science together with six other colleges of the University of the Philippines. ${ }^{106}$ Act No. 1870 or An Act for the Purpose of Founding a University for the Philippine Islands was enacted in a special session of the Philippine legislature on 18 June 1908 and it provided for the creation of the University of the Philippines. One of the first colleges that opened in 1908 was the College of Veterinary Science. ${ }^{107}$

The College of Veterinary Science was established to train and develop a body of competent veterinarians "whom the country will depend on for the control and eradication of animal epidemics that constantly threaten her animal population' ${ }^{108}$ and who could 'give advice to the owner[s] of livestock ... [on] various diseases and ailments' ${ }^{109}$ that were decimating the domestic animal population in the Philippines. University of the Philippines President Murray Simpson Bartlett noted the significance of establishing a veterinary college when he observed that 'the service of expert veterinarians is an absolute necessity in furthering the development of the immense agricultural resources of the Philippine Islands' ${ }^{110}$

The first campus of the College of Veterinary Science was located in Pandacan, Manila, adjoining the quarantine yards of the Bureau of Agriculture and near the Pandacan Animal Quarantine Station. ${ }^{111}$ When classes formally started in

103 Worcester, The Philippines, 419.

104 United States Bureau of Insular Affairs, Report of the Philippine Commission, 1907 (Washington, DC: Government Printing Office, 1908), 2: 46.

105 Manuel D. Sumulong, 'The Establishment and Growth of the College of Veterinary Science', Philippine Journal of Animal Industry 3, no. 2 (1936): 80.

106 Vicente Ferriols, 'A Brief Resume of Rinderpest Control Work in the Philippines', Philippine Journal of Agriculture (1929): 396.

107 Aside from the College of Veterinary Science, other colleges that opened in 1908 included the College of Philosophy, Science, and Letters; the College of Law, Social, and Political Science; the College of Medicine and Surgery; the College of Engineering; the College of Mines; the College of Agriculture; and the School of Fine Arts. See Mauro F. Manuel, Mario S. Tongson, Teodulo M. Topacio Jr. and Grace D. De Ocampo, A Century of Veterinary Medicine in the Philippines, 1898-1998 (Quezon City: University of the Philippines Press, 2002), 448-9.

108 Gregorio San Agustin, 'Address by Gregorio San Agustin', Philippine Journal of Animal Industry 3 (March-April 1936): 54.

109 W. H. Boynton, foreword to Philippinensian, 167.

110 Manuel D. Sumulong, 'The Outlook of a Filipino Veterinarian', in Philippinensian, 295.

111 Sumulong, 'The Outlook of a Filipino Veterinarian', 26. 
June 1910, construction of the buildings of the veterinary college was not yet complete. Hence, classes were temporarily conducted at the Philippine Medical School compound in Calle Herran, Manila. ${ }^{112}$ Only in 1912 were the veterinary college buildings finally finished. ${ }^{113}$ The College of Veterinary Science also maintained an animal clinic located between Rizal Avenue and Calle Tayuman in Manila. Its clinic occupied an area adjoining the grounds of the San Lazaro Hospital used in earlier times as an immunisation station of the Bureau of Agriculture.

On 17 May 1911, the college transferred to San Lazaro district at the corner of Tayuman Street and Rizal Avenue, adjoining the San Lazaro Hospital, because many students complained of the difficulty of attending their classes in two widely separated campuses. ${ }^{114}$ The new site was perfect for the college because clinical materials needed by veterinary science students were available at the San Lazaro racetrack. ${ }^{115}$

On 9 February 1933, Victor Buencamino, the Director of the Bureau of Animal Industry, proposed to the Secretary of the Department of Agriculture and Commerce the return of the College of Veterinary Science to Pandacan, Manila. A joint committee made up of representatives from the College of Agriculture, the College of Veterinary Science, and the School of Forestry studied the proposal. In March 1933, the committee members agreed to transfer the College of Veterinary Science back to Pandacan. ${ }^{116}$

112 The Philippine Medical School was formally opened on 10 June 1907. When it started, the school occupied the old building of the School for the Deaf and Blind located on Malecon Drive, Manila (a seaside boulevard leading to Luneta, which is now called Bonifacio Drive). On 1 June 1910, the school was transferred to Calle Herran (today Pedro Gil, Manila). The Philippine Medical School became the College of Medicine and Surgery with the enactment of Act No. 1870. See Alvin Broerman, 'The College of Veterinary Science, University of the Philippines', Philippine Agricultural Review 4 (June 1911): 289.

113 Fernando A. Bernardo, Pictorial History of UPLB (Los Baños: University of the Philippines Los Baños Alumni Association, 2007), 36.

114 L. M. Yutuc, 'The College of Veterinary Medicine', in The College of Veterinary Medicine: Golden Jubilee Commemorative Volume 1960 (Quezon City: University of the Philippines, 1960), 2.

115 Yutuc, 'The College of Veterinary Medicine', 2.

116 Buencamino suggested the great advantage of this move for the Bureau of Animal Industry, which was then located in Pandacan, Manila. Faculty members and students of the college unanimously endorsed the move to return it to Manila. The faculty of the college adopted a resolution petitioning the Board of Regents to approve the above-mentioned proposal. In their petition, the faculty affirmed that the proposal of the bureau would be for the betterment of the institution and would provide benefits to the country's veterinary profession. See Sumulong, 'The Establishment and Growth of the College of Veterinary Science', 118-19. 


\section{Development of a vaccine against rinderpest, 1920s-30s}

The Bureau of Agriculture, and its successor, the Bureau of Animal Industry, supported all endeavours to develop a vaccine against animal contagions. Prior to the development of a vaccine against rinderpest, veterinary experts used the anti-rinderpest serum to inoculate susceptible animals. From 1903 to 1911, veterinary surgeons implemented the anti-rinderpest serum inoculation campaign. In this programme, healthy and susceptible carabaos were inoculated with $30 \mathrm{ml}$ of anti-rinderpest serum and $1 \mathrm{ml}$ of virulent blood or blood from a sick animal. This method gave healthy animals the disease and the remedy at the same time. ${ }^{117}$ As noted, field trial results showed that an animal needed to be injected with 20 to $30 \mathrm{ml}$ of serum 10 to 15 times for it to receive immunity, but unfortunately trials also proved that the inoculated animal acquired only temporary immunity. For these reasons, the use of the anti-rinderpest serum was discontinued in 1911. ${ }^{118}$ Aside from its failure to provide immunity, the programme was also discontinued because, as noted, many Filipino animal owners did not cooperate with the American veterinarians because they expected veterinarians and inoculators to give medicine to their sick carabaos.

In the 1920s, Filipino and American veterinarians made a significant breakthrough in Philippine veterinary science when they finally developed the long-awaited cure for rinderpest. Once considered as the scourge of the livestock population, rinderpest was finally eradicated in the Philippines with the discovery of the anti-rinderpest vaccine. The development of the vaccine against rinderpest took place in two countries. In 1902, Dr C. Kakizaki published in Japan the results of his experimentation on the use of spleen virus in glycerine as an immunising agent. The vaccine was made from glycerinated organ pulp. ${ }^{119}$ In the Philippines, Dr William H. Boynton, research pathologist of the Bureau of Agriculture and professor of Veterinary Science at the University of the Philippines College of Veterinary Science, studied different body organs to be used in the development of the rinderpest vaccine. ${ }^{120}$ After years of studies and experimentation, Dr Boynton successfully developed a more effective rinderpest vaccine in 1923. The vaccine contained blood and finely ground tissues taken from a highly

117 United States Bureau of Insular Affairs, Report of the Philippine Commission, 1904 (Washington, DC: Government Printing Office, 1905), 2: 378; United States Bureau of Insular Affairs, Report of the Philippine Commission, 1906 (Washington, DC: Government Printing Office, 1907), 47, 117; Robles, 'Experiments on the Virulence of Rinderpest Blood', 307.

118 Kern, 'The Use of Anti-Rinderpest Serum in the Field', 243; Youngberg, 'A Brief History of Rinderpest in the Philippine Islands', 207-9, 215.

119 See C. A. Spinage. Cattle Plague: A History (New York: Springer Science+Business Media, 2003), 425-6. 120 Robles, 'Notes on Vaccines and Sera Prepared by the Bureau of Animal Industry', 266; Juan Generoso, 'Rinderpest in the Philippines', in Bureau of Plant Industry, Bureau of Animal Industry and the Fiber Inspection Service, A Half Century of Philippine Agriculture (Manila: Liwayway Publications, 1952), 345. 
susceptible animal that had been artificially injected with virulent rinderpestinfected blood. It also contained phenol, glycerin, and salt solution. When the Boynton vaccine was used in the field, deaths due to rinderpest were drastically reduced: in 1927 , to $2,123 .{ }^{121}$

Despite its effective application in the field, the Boynton vaccine was far from perfect. In February 1926, the United States Army Medical Department Research Board, at the request of Governor-General Leonard Wood and the Bureau of Agriculture, conducted a study to improve the vaccine. Major Raymond Kelser led the group that conducted the study. The other members of the group were Dr Stanton Youngberg, Dr Teodulo Topacio, and Dr Ildefonso Patdu from the University of the Philippines College of Veterinary Science. The Rockefeller Foundation funded Kelser's research team. ${ }^{122}$ After months of experimentation, the research team concluded that chloroform in proper proportion to a mixture of blood and finely ground tissues from an animal killed in the acute stages of rinderpest was able to kill the rinderpest virus. It led to a rapid decrease in the number of deaths due to rinderpest. The Bureau of Animal Industry used this same vaccine for six years. In that period, there were fewer than 200 deaths due to rinderpest. ${ }^{123}$

Despite its initial success, the Kelser chloroform-treated wet tissue vaccine was not without problems. The Bureau of Animal Industry found that if the vaccine was not properly refrigerated, it perished within 48 hours. This made the vaccine difficult to use in certain parts of the Philippines where transportation facilities were poor and the supply of ice was not assured. In 1931, Manuel Robles and Juan Generoso, two Filipino veterinarians from the Veterinary Research Division, modified the dry rinderpest vaccine to extend its shelf life. Since the vaccine did not need refrigeration, it was extensively used even in the remotest parts of the country. Its application successfully controlled the spread of rinderpest in the Philippines. By 1934, rinderpest infection was confined to the provinces of Isabela, Negros Oriental, and Negros Occidental, with only 79 deaths recorded. ${ }^{124}$

By 1935, rinderpest was no longer a threat to the cattle and carabao population. According to the Bureau of Animal Industry, it was confined to isolated areas in the provinces of Negros Occidental and Negros Oriental in the Visayas. Two years later, in 1937, the combined use of Kelser's wet tissue vaccine and the

121 Gomez, 'Eradication and Control of Rinderpest in the Philippine Islands', 110.

122 Buencamino, Memoirs, 108-9.

123 Buencamino, Memoirs, 108-9, 378-80.

124 For an extensive discussion of the work of Drs Robles and Generoso on the modified dry rinderpest vaccine, see Manuel M. Robles and Juan D. Generoso, 'Progress Report on Dried Rinderpest Vaccine', Philippine Journal of Agriculture 2 (1931): 341-5; and Teodulo Topacio, 'Preservation and Purification of Dry Rinderpest Vaccine', Philippine Journal of Animal Industry 4 (1937), 379-88. 
dried powdered vaccine proved very effective: no case of death due to rinderpest was recorded. While several cases were discovered in the following year, the infection was isolated and easily checked by the Bureau of Animal Industry. In 1939, the Bureau did not receive notice of a single case of rinderpest. For this reason, the Bureau of Animal Industry officially declared the Philippines rinderpest-free. ${ }^{125}$

Table 2 shows the number of cases and deaths due to rinderpest and the type of vaccination given to animals in 1923-39.

Table 2: Prophylactic treatment used against rinderpest, 1923-39.

\begin{tabular}{|l|l|l|l|l|}
\hline Year & Cases & Deaths & $\begin{array}{l}\text { Doses of Rinderpest Vaccine } \\
\text { Used }\end{array}$ & Type of Vaccination Used \\
\hline 1923 & 27,505 & 23,220 & 44,345 & Phenolized, 3 injections \\
\hline 1924 & 19,599 & 15,350 & 385,098 & Phenolized, 3 injections \\
\hline 1925 & 14,143 & 10,747 & 286,141 & Phenolized, 3 injections \\
\hline 1926 & 9,824 & 7,470 & 397,128 & Phenolized, 3 injections \\
\hline 1927 & 3,013 & 2,123 & 497,743 & $\begin{array}{l}\text { Phenolized, 3 injections; and } \\
\text { chloroform-treated, single injection }\end{array}$ \\
\hline 1928 & 3,650 & 2,695 & 249,893 & Chloroform-treated, single injection \\
\hline 1929 & 4,069 & 3,105 & 442,533 & Chloroform-treated, single injection \\
\hline 1930 & 1,659 & 1,420 & 400,333 & Chloroform-treated, single injection \\
\hline 1931 & 1,325 & 951 & 112,928 & Chloroform-treated, single injection \\
\hline 1932 & 196 & 139 & 390,500 & Chloroform-treated, single injection \\
\hline 1933 & 529 & 297 & 224,373 & Chloroform-treated, single injection \\
\hline 1934 & 134 & 79 & 53,846 & Dried, single injection \\
\hline 1935 & 79 & 39 & 7,000 & Dried, single injection \\
\hline 1936 & 101 & 46 & 38,840 & Dried, single injection \\
\hline 1937 & 0 & 0 & 21,200 & Dried, single injection \\
\hline 1938 & 35 & 26 & 18,480 & Dried, single injection \\
\hline 1939 & 0 & 0 & 11,358 & Dried, single injection \\
\hline
\end{tabular}

Source: Angel K. Gomez, 'Eradication and Control of Rinderpest in the Philippine Islands', Journal of the American Veterinary Medical Association 113, no. 857 (August 1948): 110.

125 Commonwealth of the Philippines, Annual Report of the Bureau of Animal Industry for the Period January 1 to December 31, 1935, 9-10, 143; Annual Report of the Bureau of Animal Industry for the Fiscal Year Ending December 31, 1937, 16-17; Semi-Annual Report of the Bureau of Animal Industry from January 1 to June 30, 1939, 14. 


\section{Conclusion}

The American colonial government's assertion of its role as an 'instigator and active participant in the dissemination of scientific knowledge ${ }^{\prime 26}$ in the Philippines was clearly manifested in its attempt to control and eradicate the spread of rinderpest in the Philippines. The application of scientific knowledge through the implementation of modern veterinary policies in the colonial Philippines provided a new way of understanding the Western constructs of the tropics as both physical and conceptual spaces. ${ }^{127}$ The necessity to control the spread of animal contagions in the Philippines shows the American colonial government's desire to conquer the Philippines not just in terms of physical space or colonial territory, but also as a conceptual territory. Yet the American colonial government failed to master nature in the tropics by simply implementing policies that many Filipinos considered culturally insensitive.

In this study, the dominance of the American colonial state over its colony was particularised in the study of animal contagions or epizootics and the coloniser's successful application of modern scientific knowledge. As the new colonial elite who actively participated in the study of the health problems of domestic animals in the tropics, they in the process created 'scientific developments' and produced medical specialisation in the diseases of 'warm climates' ${ }^{128}$ In this research, the emphasis given by American colonial officials to the control of the spread of animal contagions in the Philippines led to the advancement of a specialised medical field in the colony-the development of Philippine veterinary science.

In their attempt to control nature and assert their dominion over the Philippines' tropical environment, American colonisers instituted an extensive campaign against rinderpest, the most infectious animal contagion or epizootic recorded in the country. The earliest solution implemented by the Americans to address the rinderpest problem was the establishment of agencies, both government and academic institutions, to lead the campaign against the spread of animal contagions and to produce a new breed of Filipino veterinarian in the colony. They established the Bureau of Agriculture and its successor, the Bureau of Animal Industry, as principal agencies tasked with controlling animal contagions. The colonial government also opened the first veterinary college anywhere in Southeast Asia, the University of the Philippines College of Veterinary Science, to train Filipino veterinarians. 
Apart from establishing institutions, American colonial officials also enacted policies to control the extent of infection of the contagions in the Philippines. In 1902, American veterinarians implemented the serum inoculation programme, but it was considered a failure because of the high mortality rate incurred. Five years later, agricultural officials imposed a strict animal quarantine policy to control animal movement and thereby the spread of contagions. The quarantine programme was implemented by American veterinary officials against rinderpest in a similar manner to that by which they addressed the cholera epidemic in the Philippines during the early 1900s. ${ }^{129}$ Like the cholera-infected Filipinos, the sick carabaos and cattle were viewed by the colonisers as 'degenerate types' that, according to Anderson, required 'constant surveillance, instruction, and sometimes isolation' ${ }^{130}$ Because of such views, the Americans' policy required the application of isolation or quarantine measures to all sick animals.

Many Filipinos considered the serum inoculation programme and the animal quarantine policy as both evil and heartless because they separated Filipino livestock owners from their animals and failed to consider the economic value of the carabao to the farmer. Detaching the carabao from the farmer was tantamount to paralysing the farmer's only source of income since the carabao was the farmer's life and his main source of livelihood. Without his beast of burden, he could not cultivate his rice fields.

An anti-rinderpest vaccine was developed by Dr William Boynton in 1923 and improved later by Filipino veterinarians to ensure its effectiveness. With the vaccine's application in the field, total eradication of the contagion was achieved in the Philippines by 1939. However, the road travelled towards the long-awaited cure for rinderpest was very difficult. Many farmers had lost their work animals during the campaign because many carabaos and cattle died due to the ineffective serum introduced by the American veterinarians. During the entire campaign of the Americans against rinderpest, the colonisers transformed the Philippines into a tropical laboratory where the farmer and his work animal were made into laboratory subjects. As the American veterinary experts worked on the cure to the disease on a trial-and-error basis, the Filipino's sentimentality, his emotional attachment to his beast of burden, and his culture were ignored. And worse, their negative reactions towards the policies were criticised by American colonial officials who stated that the Filipinos were simply ignorant of Western science. Success may have been achieved in the control and eradication of epizootics in the Philippines. America may have achieved its goal to end the spread

129 See Reynaldo Ileto, 'Cholera and the Origins of the American Sanitary Order in the Philippines', in Discrepant Histories: Translocal Essays on Filipino Cultures, ed. Vicente L. Rafael (Manila: Anvil Publishing, 1995), 51-81.

130 Warwick Anderson, “Where Every Prospect Pleases and Only Man is Vile": Laboratory Medicine as Colonial Discourse', in Discrepant Histories: Translocal Essays on Filipino Cultures, ed. Rafael, 100. 
of rinderpest in the Philippines and considered it as an important legacy in Philippine veterinary science, but the programme to combat the disease was a brutal and heartless one to Filipino farmers. Even as the instigator and active participant in the dissemination of scientific knowledge, the American colonial state failed to win the support of the Filipino farmers to help them solve the epizootics problem because they did not consider the cultural dimension of their scientific policies. 
This text is taken from International Review of Environmental History, Volume 2, 2016, edited by James Beattie, published 2016 by ANU Press, The Australian National University, Canberra, Australia. 